\title{
Bacterial utilization of humic substances from the Arctic Ocean
}

\author{
Ingeborg Bussmann*
}

Alfred-Wegener-Institut für Polar- und Meeresforschung, Am Handelshafen 12, 27570 Bremerhaven, Germany

\begin{abstract}
The main water exchange between the Arctic and the Atlantic oceans takes place at the Fram Strait. Humic substances (HS), derived from the whole Arctic, are included within the water entering the Atlantic. Batch experiments were set up to investigate the bioavailability of the Arctic HS to bacteria and to characterize any controlling factors. HS were extracted with XAD resins 2 and 4 , and served as the sole carbon source for bacteria. Leucine incorporation rate, oxygen consumption, bacterial cell counts and dissolved organic carbon (DOC) concentrations were monitored for the experiments. Overall, $11 \%$ of the initial carbon was consumed and a turnover time of $220 \mathrm{~d}$ was extrapolated for marine HS in polar surface waters and a profound temperature dependence was observed $\left(Q_{10}=2.9\right.$ to 4.8). Comparing the bioavailability of HS from surface water with that of sea water-DOC revealed no significant differences, with both showing the same quality as a bacterial carbon source. Additionally, the bioavailability of HS from surface water was compared with that of HS from deep water. This comparison revealed that surface HS are of significantly better bacterial food quality than deep water HS. The experiments indicated that marine HS play an active role in bacterial carbon cycling in the Arctic Ocean.
\end{abstract}

KEY WORDS: XAD-resin $\cdot$ DOC $\cdot$ Fram Strait - Bioavailability

\section{INTRODUCTION}

Humic substances (HS) constitute the largest fraction of dissolved organic matter (DOM) in most natural waters (Thurman 1985) and for a long time have been considered biologically inert. This assumption originates mainly from freshwater and soil studies, where HS may even have inhibitory effects on bacterial growth (Kontchou \& Blondeau 1990). Recent studies from the marine environment, however, show that HS can be used as a carbon source by bacteria, with all the associated biogeochemical implications (Moran \& Hodson 1994, Bano et al. 1997). Most studies on the bioavailability of HS have focused on estuaries or coastal areas with high allochthonous input of HS. Less attention has been paid to areas with low terrestrial

\footnotetext{
- Present address: University of Konstanz, LS Microbial Ecology, PO Box 5560, 78434 Konstanz, Germany.

E-mail: ingeborg.bussmann@uni-konstanz.de
}

input and correspondingly autochthonous marine HS. In contrast to terrestrial-derived HS with high phenol and lignin content (Opsahl \& Benner 1995), seawater HS are essentially aliphatic and considered to be of phytoplankton origin (Ishiwatari 1992).

The Fram Strait, located between Greenland and Svalbard, is an area of intensive exchange of water masses between the Polar Ocean and the North Atlantic. The upper layer of the Arctic Ocean is characterized by cold, low salinity water (polar mixed surface water). The polar mixed surface water of the Fram Strait is composed of water masses of different origin, e.g. returning Atlantic water and Pacific water (Rudels 1989, Jones et al. 1998), superimposed with strong local influences such as melting ice floes and an enhanced primary production (Smith et al. 1985, Thomas et al. 1995). Therefore the terrestrial influence of the large Siberian rivers is considered to be minor in the surface waters of the Fram Strait. A well-developed halocline separates the surface layer from the large body of Arctic Ocean deep water. The outflow of the saline Arctic 
Ocean deep water to the Greenland Sea, through the western Fram Strait, provides a direct connection between the deep thermohaline circulation of the Arctic Ocean and the seas to the south (Aagaard et al. 1991). As DOM is also encompassed in this water mass exchange, it is therefore important to know more about the characteristics and the bioavailability of the Arcticderived DOM entering the Atlantic.

This study focuses especially on the bacterial utilization of HS, as a presumably stable part of Arctic DOM being exported into the Atlantic. Batch experiments were set up to investigate the mechanisms regulating the bioavailability of $\mathrm{HS}$ in a polar marine system with low concentrations of total DOM and low temperatures.

\section{MATERIAL AND METHODS}

From August to September 1997, RV 'Polarstern' crossed the Fram Strait from Greenland to Svalbard (Krause 1998 ) at about $80^{\circ} \mathrm{N}$ (Table 1). Water samples (20 l) were taken with Niskin bottles from a rosette and transferred immediately to a dark, constant-temperature room $\left(0^{\circ} \mathrm{C}\right)$, where the samples were processed. All experiments were carried out on board

Bacteria were extracted from $20 \mathrm{l}$ of seawater using 2 stirred ultrafiltration cells (Amicon 8400). The autoclaved cells were connected with Teflon tubing. The first cell served as a prefilter $(0.8 \mu \mathrm{m})$ to remove most grazers, with the second filter $(0.2 \mu \mathrm{m})$ concentrating bacterial cells. The filtration was gravity driven by placing the sample container and the filtration cells on different levels, ca $1 \mathrm{~m}$ apart. To prevent the filters from clogging, the water was stirred slowly all the time. Filtration was done at $0^{\circ} \mathrm{C}$ in the dark with a flow rate of ca $11 \mathrm{~h}^{-1}$. The first 4 to $5 \mathrm{l}$ were discarded. At the end of the extraction process, the supernatant of the $0.2 \mu \mathrm{m}$ filter (generally $200 \mathrm{ml}$ ) was taken as inoculum. Bacterial concentration in the experiments was ca $10 \%$ of the naturally occurring concentration.
The incubation medium was artificial seawater and contained the following salts $\left(\mathrm{g} \mathrm{l}^{-1}\right)$ : $24 \mathrm{NaCl}_{\text {; }}$ $5.3 \mathrm{MgCl}_{2} \cdot 6 \mathrm{H}_{2} \mathrm{O} ; 7 \mathrm{MgSO}_{4} \cdot 7 \mathrm{H}_{2} \mathrm{O} ; 0.7 \mathrm{KCl}_{i} 0.1 \mathrm{CaCl}_{2}$ - $2 \mathrm{H}_{2} \mathrm{O}$. Trace element solution was added at a concentration of $1 \mathrm{ml} \mathrm{l}^{-1}$ (Pfennig et al. 1981). $\mathrm{KNO}_{3}$ $(400 \mu \mathrm{M})$ served as a nitrogen source and the medium was buffered with $200 \mu \mathrm{MPO}_{4}\left(\mathrm{Na}_{2} \mathrm{HPO}_{4} / \mathrm{KH}_{2} \mathrm{PO}_{4}\right)$ and $200 \mu \mathrm{M} \mathrm{NaHCO}$ (all final concentrations) to a $\mathrm{pH}$ of 7.3 to 7.5

HS were extracted with XAD 2 and 4 resins (Serva), with pore sizes of 9 and $5 \mathrm{~nm}$ respectively. The resins had been cleaned intensively by Soxlett distillation according to Malcolm (1989). Each resin $(30 \mathrm{ml})$ was packed into a liquid chromatography column. The filtrate from the bacteria concentration was used for HS extraction after adjusting the $\mathrm{pH}$ to 2 with $\mathrm{HCl}$. Within $24 \mathrm{~h}$, the filtrate ran through the XAD columns - first XAD 2 followed by XAD 4. Thereafter, the columns were rinsed with $200 \mathrm{ml}$ of $0.01 \mathrm{~N} \mathrm{HCl}$ to remove salts. The HS were finally eluted with $200 \mathrm{ml}$ of $0.1 \mathrm{M}$ $\mathrm{NaOH}$ for the acid fraction (Hb A), followed by $200 \mathrm{ml}$ methanol for the neutral fraction $(\mathrm{Hb} N)$. To eliminate $\mathrm{MeOH}$, the sample was processed 3 times in a rotary evaporator with Milli-Q water. The hydrophilic fraction $(\mathrm{H} \mathrm{I})$ was the effluent of the resins, taken after approximately $10 \mathrm{l}$ had passed through the columns. For the experiments, the buffers were added immediately to the eluate and the $\mathrm{pH}$ was adjusted to $\mathrm{pH} 7$. Preliminary experiments with Arctic surface water had shown that about $40 \%$ of the DOC was retained and could be eluted from the resins. Blanks with Milli-Q water showed no increase of DOC in neither the effluent nor in the eluate (author's unpubl. data).

Five experiments were set up to assess the bioavailability of Arctic HS (Table 1). In Expt 1, to assess the influence of carbon concentration (HS concentration) on carbon consumption rate (HS consumption), the concentration of HS ranged from 18 to $168 \mu \mathrm{M} \mathrm{C}$. Temperature dependence of the HS degradation was investigated in Expt 2, with temperatures ranging from -1 to $10^{\circ} \mathrm{C}$. Expt 3 compared the different HS fractions

Table 1 The different experiments, location of the sample stations and the natural concentrations of DOC and humic substances (HS) $(n=3)$

\begin{tabular}{|c|c|c|c|c|c|c|c|}
\hline \multicolumn{2}{|c|}{ Expt } & Position & Water depth & HS fraction & \multirow{2}{*}{$\begin{array}{c}\text { DOC } \\
(\mu \mathrm{MC}) \\
110 \pm 5\end{array}$} & \multirow{2}{*}{$\begin{array}{c}\mathrm{HS}^{\mathrm{b}} \\
(\mu \mathrm{M} \mathrm{C}) \\
18 \pm 5\end{array}$} & \multirow{2}{*}{$\begin{array}{l}\% \mathrm{HS}^{b} \text { of } \\
\text { total DOC } \\
16\end{array}$} \\
\hline $\begin{array}{l}1 \\
2\end{array}$ & $\begin{array}{l}\text { Substrate concentration } \\
\text { Temperature }\end{array}$ & $77^{\circ} 55^{\prime} \mathrm{N}, 5^{\circ} 18^{\prime} \mathrm{W}$ & $26 \mathrm{~m}$ & $\mathrm{Hb} \mathrm{A}$ & & & \\
\hline 3 & Different HS fractions & $80^{\circ} 53^{\prime} \mathrm{N}, 2^{\circ} 34^{\prime} \mathrm{W}$ & Surface & Hb A, Hb N, H I, Seawater & $122 \pm 8$ & $27 \pm 3$ & 22 \\
\hline 4 & Deep water & $81^{\circ} 05^{\prime} \mathrm{N}, 2^{\circ} 02^{\prime} \mathrm{W}$ & $3394 \mathrm{~m}$ & $\mathrm{Hb} \mathrm{A}$ & $47 \pm 2$ & $17 \pm 4$ & 36 \\
\hline 5 & Surface water & $81^{\circ} 02^{\prime} \mathrm{N}, 7^{\circ} 47^{\prime} \mathrm{W}$ & $20 \mathrm{~m}$ & $\mathrm{Hb} \mathrm{A}$ & $83 \pm 0$ & $22 \pm 1$ & 27 \\
\hline
\end{tabular}


with total seawater. In this experiment, the seawater, and the $\mathrm{Hb} \mathrm{A}$ and $\mathrm{Hb} \mathrm{N}$ fractions were diluted with artificial seawater to obtain the same initial DOC concentrations as in the H I fraction. In Expts 4 and 5 the bioavailability of surface versus deep water HS was compared.

Incubations were done at $0^{\circ} \mathrm{C}$ (unless otherwise stated) in $1 \mathrm{l}$ acid-rinsed glass bottles. Bacteria were added to the medium immediately after filtration. The experiments started with the addition of the HS to the prepared bottles. In general, the concentration of the HS was set at 2.5 times the natural concentration. Samples for cell counts, dissolved organic carbon (DOC) concentration, leucine incorporation rate and oxygen consumption were taken over a time period of up to $400 \mathrm{~h}$. All settings were run in duplicate $(\mathrm{a} / \mathrm{b})$

Negative controls were set up without bacteria or without HS. Positive controls were prepared and grown with glucose and acetate (150 $\mu \mathrm{M}$ each) as the labile carbon source and also with HS added to the glucose and acetate.

Samples for DOC determination were stored frozen in precombusted glass ampoules. The samples were not filtered and therefore included bacterial carbon. Back in the laboratory, DOC was analyzed by high temperature combustion, using a Shimadzu TOC 5000 analyzer equipped with an auto sampler. Potassium hydrogen phthalate was used as the standard substance. Before injection, samples were acidified with $\mathrm{HCl}$ to $\mathrm{pH} 2$ and sparged for $10 \mathrm{~min}$ to remove the inorganic carbon as $\mathrm{CO}_{2}$. Samples from 1 time series were measured on the same day, each series starting with the lowest concentrations.

Measurements of ${ }^{3} \mathrm{H}$-leucine incorporation rate (LEU) were carried out, according to the methods of Chin-Leo \& Kirchman (1988). Leucine with a specific activity of $58.0 \mathrm{Ci} \mathrm{mmol}^{-1}$ (Amersham) was used and added to a final concentration of $10 \mathrm{nM}$. To increase the sensitivity, $20 \mathrm{ml}$ samples were incubated for $6 \mathrm{~h}$ at $0^{\circ} \mathrm{C}$ with the incubations done in triplicate. Tests showed that LEU was still linear over $6 \mathrm{~h}$ incubation time, but with a lower variability. Formalin-killed samples served as blanks. Incubation was stopped by filtration onto nucleopore filters and, after extraction of proteins with ice cold 5\% TCA, the filters were frozen. In the laboratory, the filters were transferred into Filter Count Scintillation Cocktail (Packard) and radio-assayed in a Packard TriCarb liquid scintillation counter. Quench correction was performed by automatic external standardization. Initial LEU (pmol $\left.\mathrm{l}^{-1} \mathrm{~h}^{-1}\right)$ is the rate at the start of the experiment $(t=0)$.

Cumulative LEU $\int_{0 \mathrm{~h}}^{200 \mathrm{~h}} \mathrm{LEU}$ in $\mathrm{nmol}^{-1}$ is the rate integrated over $200 \mathrm{~h}$ (the shortest duration of all experiments).
For oxygen consumption rates, incubations were done in triplicate 50 and $100 \mathrm{ml} \mathrm{BOD}$ bottles. Oxygen concentrations were determined by the Winkler method with a Mettler DL 21 auto-titrator with potentiometric end-point detection (Granéli \& Granéli 1991). Respiration rates were calculated from the slope of a linear curve of $\mathrm{O}_{2}$ concentration versus incubation time. The lag phase, before a measurable $\mathrm{O}_{2}$ consumption started, was omitted.

Growth yield was calculated using the formula GY $(\%)=\operatorname{prod} /(\operatorname{prod}+\operatorname{resp}) \times 100$. Prod being the bacterial carbon produced, based on LEU, which was converted into bacterial carbon (Simon \& Azam 1989), and resp being the bacterial carbon respired, based on oxygen consumption, which was converted into carbon consumption with the ratio 1:1 (Pomeroy et al. 1995).

Acridine orange direct counts (AODC) of bacteria were determined by epifluorescence microscopy. The samples were fixed with $1 \%$ formaldehyde (final concentration), filtered onto black $0.2 \mu \mathrm{m}$ nucleopore filters (Costar) and subsequently stained with $0.01 \%$ acridine orange. Microscopic analyses were carried out with a Zeiss Axioskop 20. Cell counts were further used to calculate the growth rate $\left(\mu=\left[\ln N t_{2}-\ln N t_{1}\right] / t_{2}-t_{1}\right)$, doubling time $\left(t_{\mathrm{D}}=1 / \mu\right)$ and lag time $\left(t_{\mathrm{L}}=t_{2}-\left[\left\{\ln N t_{2}-\right.\right.\right.$ $\left.\ln N t_{1} y / \mu\right]$ ) according to Schlegel (1985). $N$ being the number of cells at sampling point $t_{1}$ or $t_{2}$.

The $Q_{10}$ values were determined for the temperature range -1 to $10^{\circ} \mathrm{C}$ and calculated from the slope of the conventional Arrhenius plot (the natural logarithm of the rate versus the inverse of absolute temperature) using the expression $Q_{10}=\exp \left(-10 \times m / T^{-2}\right.$ is $)($ Raven \& Geider 1988), with $T_{\text {is }}$ being the in situ temperature $\left(0^{\circ} \mathrm{C}\right)$ in Kelvin, and $m$ as the slope of the regression line of the Arrhenius plot.

Statistical analyses were performed with StatView 4.5 for Macintosh (1994). Regression analysis was performed after log transformation and Student's $t$-tests after rank transformation of the data to obtain a normal distribution (Bortz 1985).

\section{RESULTS}

DOC concentrations in surface seawater in the Fram Straight varied between 83 to $122 \mu \mathrm{M}$, while deep water had a lower concentration, at $47 \mu \mathrm{M} C$ (Table 1). Concentrations of HS for all stations ranged from 17 to $27 \mu \mathrm{M} \mathrm{C}$. HS therefore accounted for 16 to $27 \%$ of the total surface DOC, and $36 \%$ of the 1 deep water sample (Table 1).

Controls showed that the addition of the HS concentrate (with its high salt concentration) had no effect on bacterial growth, as there was no significant difference (Wilcoxon signed rank test, $\mathrm{p}=0.92, \mathrm{n}=2 \times 6$ ) of LEU 
in the presence or absence of HS (with glucose/acetate as labile carbon source). Sterile controls showed no change of DOC over time, indicating no detectable uptake of DOC out of the surrounding air. Bacterial cell counts in controls without any added carbon source were in the range of 4 to $11 \%$ of the counts in the corresponding sample (data not shown). Samples were not corrected for these controls.

To investigate the influence of carbon concentration (HS concentration) on the carbon (HS) consumption rate, DOC data from Expt 1 (Table 1) and all DOC data from experiments with surface $\mathrm{Hb} A$ at $0^{\circ} \mathrm{C}$ were pooled $(\mathrm{n}=10)$. Initial HS concentrations ranged from 18 to $168 \mu \mathrm{M} \mathrm{C}$, and the corresponding consumption rates varied between 0.003 and $0.09 \mu \mathrm{M} \mathrm{C} \mathrm{h}^{-1}$. HS concentrations were far from reaching substrate saturation kinetics, thus a linear relationship was assumed (Fig. 1). HS consumption rate was linearly dependent on the carbon concentration $\left(\mathrm{r}^{2}=0.66, p=0.004\right)$. Assuming a mean natural concentration of $22 \mu \mathrm{M} \mathrm{C}$ (Table 1), the HS consumption at this natural concentration was calculated to be $0.1 \mu \mathrm{M} \mathrm{d}^{-1}$.

The initial HS concentration was not always in the same range in the experiments. To correct for this, I looked for relationships between initial HS concentration and the other parameters. But, apart from cumulative $\mathrm{LEU}$, none of the parameters $\left(t_{\mathrm{D}}, t_{\mathrm{L}}\right.$, initial LEU and $\mathrm{O}_{2}$ consumption) showed a significant relationship to the initial HS concentration. The cumulative LEU depended linearly on the initial HS concentration $\left(r^{2}=0.32, p=0.0059, n=22, \log\right.$-transformed data of all experiments). Thus, for the 'Discussion' and Tables 2 \& 3 only 'cumulative LEU' was corrected for different HS concentrations.

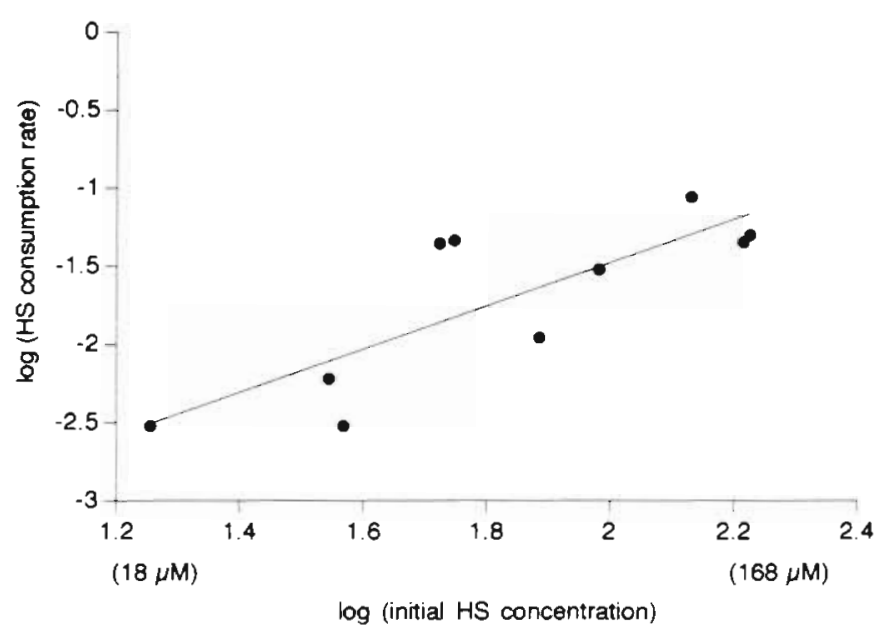

Fig. 1 Dependence of the humic substance (HS) consumption rate on the initial HS concentration, with log-transformed data. The numbers in parentheses show the actual concentrations

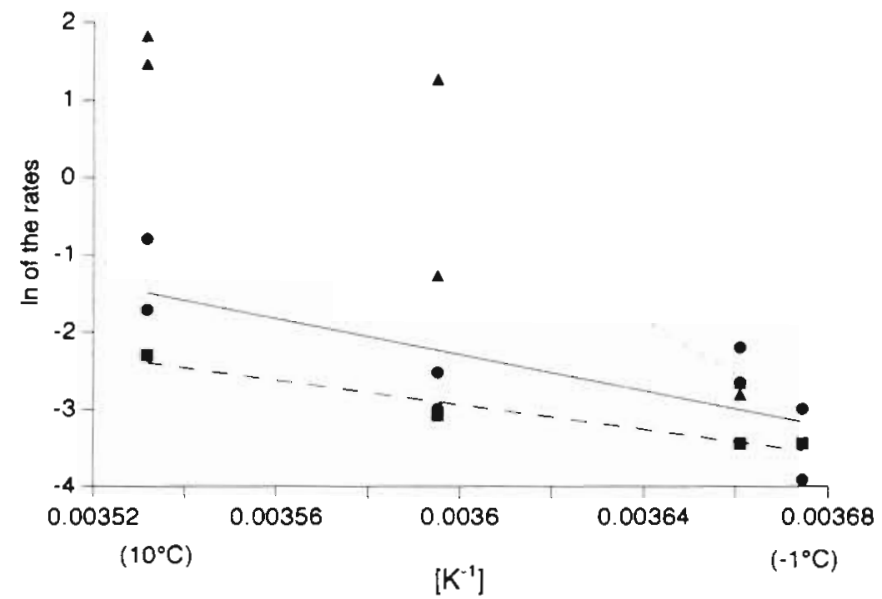

Fig. 2. Temperature dependence of oxygen consumption, initial leucine incorporation and growth yield. Measurements were made at $-1,0,5$ and $10^{\circ} \mathrm{C}$. The Arrhenius plot shows the inverse absolute temperature versus the natural logarithm of the rates as follows: $(\bullet)$ leucine incorporation rate, $(\boldsymbol{\square})$ oxygen consumption rate and ( $\mathbf{\wedge}$ ) growth yield

To assess the influence of temperature on HS degradation (Expt 2), incubations were set up at $-1,0,5$ and $10^{\circ} \mathrm{C}$. The $Q_{10}$ was calculated for the $\mathrm{O}_{2}$ consumption rate and initial LEU (Fig. 2), $Q_{10}$ ranged from $2.90 \pm$ 1.20 for $\mathrm{O}_{2}$ consumption to $4.81 \pm 1.72$ for initial LEU. There was also a significant temperature dependence for growth yield (Fig. 2), but the slope was too steep to calculate a sensible $Q_{10}$. For AODC-based variables, no temperature dependence could be calculated, as for the $-1^{\circ \prime}$ and ' $0^{\circ}$ settings no increase of cell numbers was detected.

In the third experiment the bioavailability of the seawater DOC was compared to the different HS fractions ( $\mathrm{Hb} \mathrm{A}, \mathrm{Hb} \mathrm{N}$ and $\mathrm{H} \mathrm{I}$ ). The experiment started with an initial cell concentration of $3.4 \times 10^{3}$ cells $\mathrm{ml}^{-1}$ (Fig. 3A). After $400 \mathrm{~h}$ the stationary phase was reached, with cell counts ranging from $6.57 \times 10^{4}$ $(\mathrm{Hb} \mathrm{Ab})$ to $1.36 \times 10^{6}(\mathrm{Hb} \mathrm{Aa})$, with a mean of $3.8 \times 10^{5}$. Growth rates $\left(0.02 \mathrm{~h}^{-1}\right)$ were about the same for all samples (Table 2). Lag time was highest for $\mathrm{Hb} \mathrm{Aa}$ ( $85 \mathrm{~h}$ ), while $\mathrm{H} \mathrm{Ia} / \mathrm{b}$ and $\mathrm{Hb} \mathrm{Nb}$ grew exponentially from the beginning of the experiment (Table 2). Initial LEU differed by 1 order of magnitude between 0.06 and 1.69 pmol Leu $\mathrm{l}^{-1} \mathrm{~h}^{-1}$. After an exponential increase, a mean value $( \pm \mathrm{SD})$ of $200 \pm 39 \mathrm{pmol}$ Leu $\mathrm{l}^{-1} \mathrm{~h}^{-1}$ was reached in all fractions (Fig. 3B). A mean DOC concentration of $60 \pm 14 \mu \mathrm{M}$ was measured at the beginning of the experiment, excluding $\mathrm{Hb} \mathrm{Aa}$, which started with $135 \mu \mathrm{M}$ DOC. Except for this sample, no significant decrease of DOC could be detected over time (Fig 3C). The main decrease of $\mathrm{O}_{2}$ occurred after $73 \mathrm{~h}$ (Fig. $3 \mathrm{D}$ ) and the $\mathrm{O}_{2}$ consumption rate then varied between 0.06 and $0.24 \mu \mathrm{M} \mathrm{h}^{-1}$ (Table 2) 

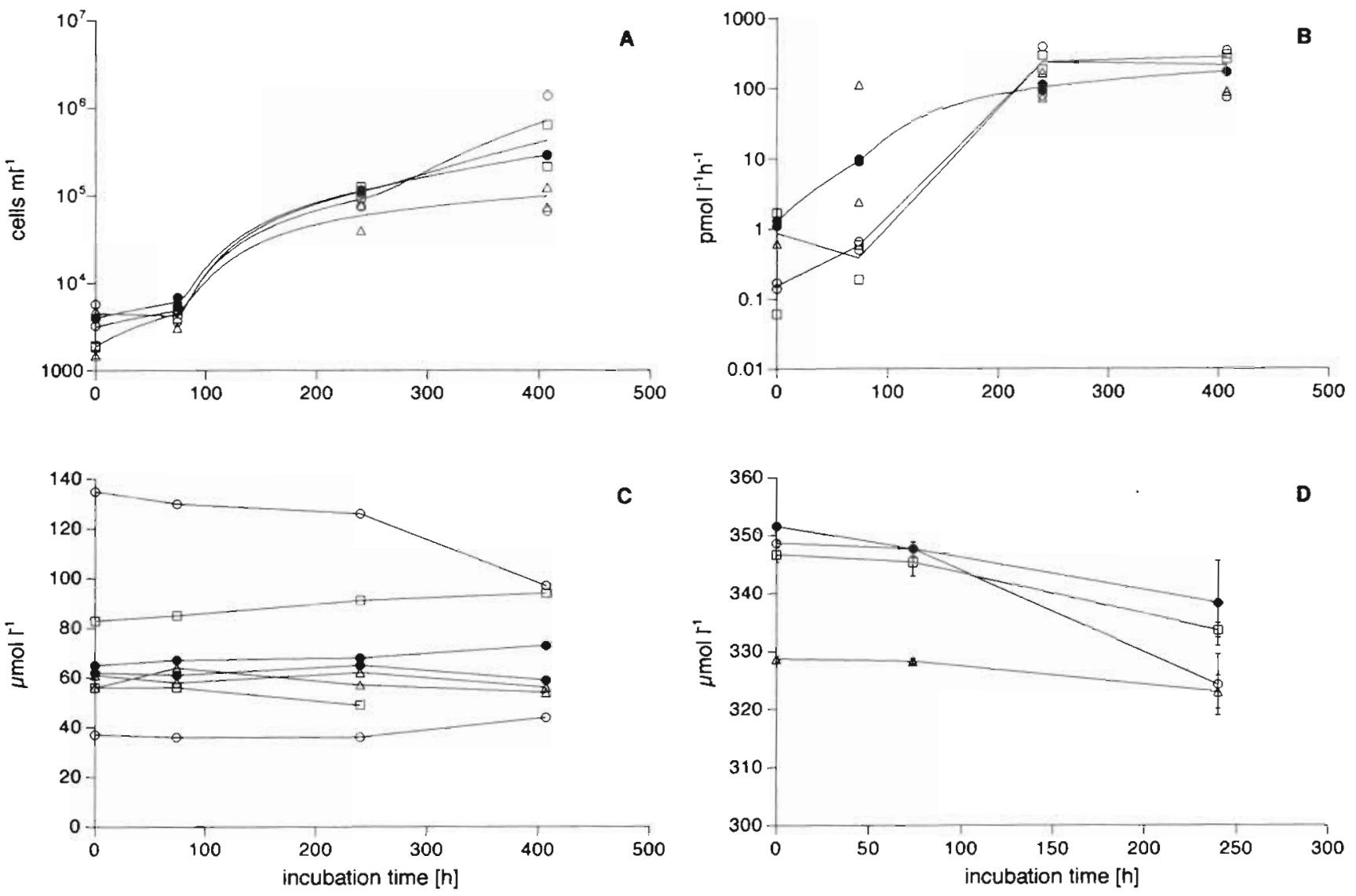

Fig. 3. Natural bacterial population, growing on different fractions of $\mathrm{HS}$ or seawater $\mathrm{DOC}$ as their sole carbon source. Showing the changes of $(A)$ acridine orange direct counts (AODC) $\mathrm{ml}^{-1}$, (B) leucine incorporation rate, (C) DOC, and (D) oxygen consumption. (Except for the $\mathrm{O}_{2}$ consumption, error bars for the standard deviation were mostly within the symbols size on the

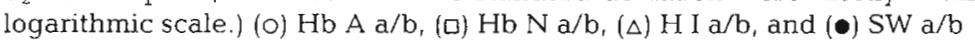

there are other factors controlling bacterial growth, but there are no simple, non-complex generalisations possible (Moriarty \& Bell 1993). Cell count based parameters depend more on the initial cell concentration of an experiment (Pitter \& Chudoba 1990). Low growth efficiencies, as observed in this study, may indicate that bacterial production was limited by factors other than DOC (Kirchman et al. 1991). It has also been reported that, at low temperatures, bacterial production will respond more slowly and to a lesser extent to the addition of carbon than at higher temperatures (Kirchman \& Rich 1997). Being restricted to macromolecules (HS) as the sole carbon source may additionally limit growth due to the rate of polymer hydrolysis (Moriarty \& Bell 1993). All this may explain the uncoupling of initial $\mathrm{LEU}, t_{\mathrm{D}}, t_{\mathrm{L}}$ and $\mathrm{O}_{2}$ consumption from the initial HS carbon concentration. However, integrating LEU over the whole incubation time, cummulative LEU is in the end dependent on the amount of carbon available.

The bacterial efficiency of carbon turnover was quite low in this study. Growth yield ranged from 1 to $20 \%$, with a mean of $8 \%$. For oligotrophic oceanic waters and humic lakes, a range of 2 to $30 \%$ is given by Middelboe \& Søndergaard (1993) for the growth yield, with about $4 \%$ calculated for the Polar Southern Ocean (Bjørnsen \& Kuparinen 1991). Middelboe \& Søndergaard (1993) showed a close coupling between growth yield and the labile part of DOC. Such a relationship was not detectable in this study, due mainly to the high variability $(\mathrm{CV}=0.82)$ of the data.

Several studies have discussed the importance of temperature versus substrate availability. In temperate regions $\left(<12^{\circ} \mathrm{C}\right)$, temperature is thought to be more important than substrate availability (Hoch \& Kirchman 1993, Shiah \& Ducklow 1994). In these studies the $Q_{10}$ varied between 2.76 and 5.60. A $Q_{10}$ of about 3 was found for the range 8 to $25^{\circ} \mathrm{C}$ (Barillier \& Garnier 1993), but in contrast with the present study, growth yield was independent from temperature. Rivkin et al. (1996) focused on cold environments and reported a much lower temperature dependence with a $Q_{10}$ of 1.4 to 1.5. As mean specific growth rates in cold and temperate regions were not significantly different, Rivkin et al. (1996) concluded that bacterial turnover in high 

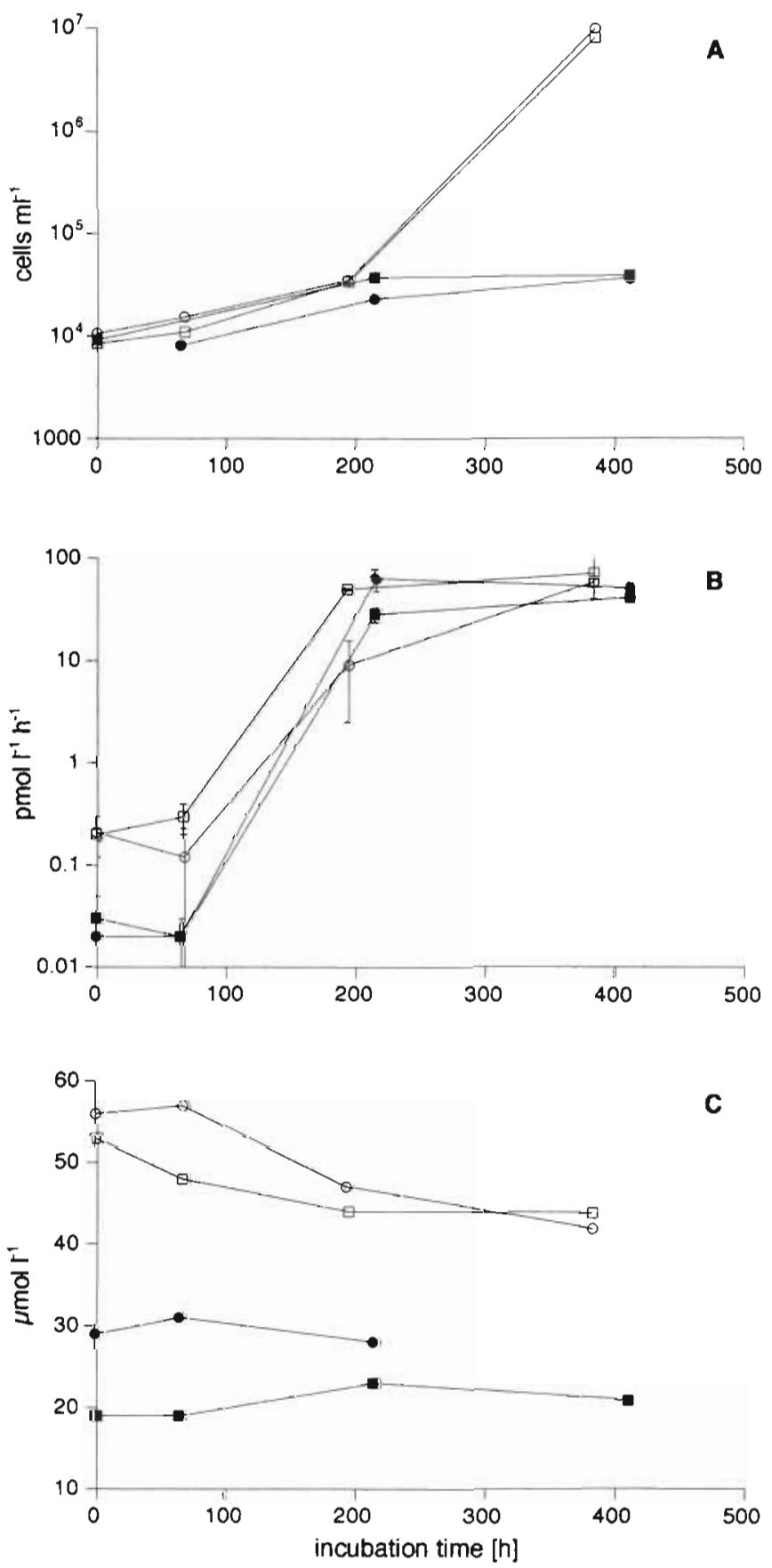

Fig. 4. Natural bacterial population, growing with HS as their sole carbon source. Showing the changes of (A) AODC $\mathrm{m}^{-1}$, (B) leucine incorporation rate, and (C) DOC. (Except for LEU, error bars for the standard deviation were mostly within the symbols size on the logarithmic scale $).(O, \square)$ Surface $H S a / b$,

$(\bullet, \mathbf{a})$ deep water HS a/b

latitudes is as important as in temperate regions, and is not hampered by low temperatures.

The observed values of $Q_{10}$ in this study (2.9 and 4.8) are in the upper range of published data. However, since these experiments were carried out at low sub- strate concentrations, and taking into account reported reciprocal interactions of temperature and substrate concentration (Rivkin et al. 1996), the importance of temperature in this study was probably increased. Because of this reciprocal interaction, bacteria will grow only slowly at both low temperature and low substrate concentration (Wiebe et al. 1992), i.e. at low concentration of HS in polar waters.

Natural seawater includes all components of DOC, while the humic fractions are supposed to be composed of mostly refractory material. Thus the hypothesis was that carbon from seawater would be of better quality as a bacterial substrate than the carbon from the humic fractions alone. The better quality should have been reflected in a shorter lag time, a faster growth rate, higher LEU and $\mathrm{O}_{2}$ consumption rates and a better growth efficiency.

To test the above hypothesis, all independent variables of Table $2\left(t_{L}, t_{D}\right.$, initial LEU, cumulative LEU and $\mathrm{O}_{2}$ consumption rate) were included in an analysis. Oxygen consumption rate was used instead of growth yield, because it was measured independently from LEU. Each column was rank transformed in such a way that the 'best' growing sample received the smallest number (for example a $t_{\mathrm{L}}$ of $0 \mathrm{~h}$ was assigned ' 1 ' vs ' 8 ' for $85 \mathrm{~h}$; whereas a sample with an initial LEU $0.06 \mathrm{pmol} \mathrm{l}^{-1} \mathrm{~h}^{-1}$ was assigned ' 7 ' vs ' 1 ' for $1.69 \mathrm{pmol} \mathrm{l}^{-1}$ $\mathrm{h}^{-1}$ ). For missing values, a neutral rank was inserted. After rank transformation (and thus also normalizing for the different units) all columns were pooled. The different fractions were compared with each other using an unpaired $t$-test. There was no significant difference between the different fractions as is illustrated by the mean ranks for each fraction: 4.3 (seawater), $4.8(\mathrm{Hb} \mathrm{A}), 5.0(\mathrm{Hb} \mathrm{N})$ and $3.6(\mathrm{H} \mathrm{I})$, respectively.

The fact that the different HS fractions did not include more refractory material than the total DOM of seawater may have several explanations. XAD resins do not extract all humic-like compounds and additional non-humic compounds may have been concentrated on the resins (Aiken 1988). Most of the studies dealing with marine HS extract them with XAD 8, and allow for the problem of extreme bleeding from this particular resin. To circumvent this problem, which is especially severe in bioavailability studies, XAD resins 2 and 4 were used. Thus, not all HS from the seawater may have been extracted. However, there are several studies describing similar extraction characteristics for resins 2 and 8 in marine waters (for example, Esteves et al. 1996), without the problem of resin bleeding. $\mathrm{XAD} 4$ was included in order to also extract small organic compounds (Aiken et al. 1992).

A more ecological point of view would lead to the question of the usefulness of XAD resins for the extraction of recalcitrant compounds. Such usefulness has 
also been questioned by Tranvik (1988) with a different methodological approach. The fact that the present study not only focused on the $\mathrm{Hb}$ A fraction, but included all $\mathrm{HS}$ fractions ( $\mathrm{Hb} \mathrm{A}, \mathrm{Hb} \mathrm{N}$ and $\mathrm{H} \mathrm{I}$ ), supports his point of view that pelagic DOC comprises a continuum of fractions of varying recalcitrance which cannot be separated by XAD resins (Tranvik 1992). Such a continuum of recalcitrance of marine DOM is also postulated by Amon \& Benner (1996), based on molecular weight classes.

DOM from surface water originates mainly from recent biological activities and is therefore considered to be of better food quality for bacteria when compared with the older material from deep water. Thus, the hypothesis was tested that surface HS are a better quality carbon source than deep water HS. As described above, this should have been reflected in a shorter lag time, faster growth rate, higher LEU and in a better growth efficiency. Reflecting the natural concentrations, the initial DOC concentrations from the surface settings were twice as high as in the deep water settings. However, as described in the 'Results', only cumulative LEU was influenced by the initial HS concentration, and thus was corrected (see Table 3 ).

To test the proposed hypothesis with the use of the independent variables in Table 3, each column was rank transformed as previously described. Then all columns were pooled, and surface HS versus deep water HS were tested (unpaired $t$-test). This showed that surface HS are of significantly better food quality than deep water HS $(p=0.002, n=16)$. Surface HS revealed a mean rank of 1.9 compared to a mean rank of 3.1 for deep water HS

Most studies on the bioavailability of marine HS were conducted with HS originating only from surface water (Tranvik 1993, Moran \& Hodson 1994), but (to my knowledge) there are no studies on the bioavailability of deep water HS. DOC from deep water is known to be older than that obtained from surface waters and it is suspected to exhibit a more refractory humic character (Bauer et al. 1992). As well as the generally lower concentration of DOC in deep water than in surface waters, the chemical composition also differs. The deeper samples from the Atlantic and Pacific are dominated by humic-type fluorescence (Mopper \& Schultz 1993), with these compounds being chemically different from surface water HS (Coble 1996). Furthermore, DOC of deep water is known to receive significant input from sedimentary organic carbon (Klinkhammer et al. 1997), probably even older than water column DOC.

To conclude, it was not surprising that this study found that HS from deep water were of lower quality as a bacterial carbon source than surface HS. Total DOC from deep water (including HS) has already been described as resistant to microbial oxidation (Barber 1968). The different quality of surface DOC versus deep water DOC is simply reflected in the HS fractions. This supports the previous findings that the different HS fractions have the same lability or recalcitrance as the total seawater DOC.

Organic material extracted from seawater with XAD resins, and therefore separated by different chemical characteristics, was shown to have no quality difference as a bacterial carbon source compared with total seawater DOC. Therefore, HS do play an active role in bacterial carbon cycling in the Arctic Ocean.

Acknowledgements. I wish to thank R. Engbrodt for co-operation in the humic extraction procedures, C. Lorenzen for assistance in cell counting, and R. Amon, P. Fischer and B. Rosenstock for helpful comments on earlier versions of the manuscript. This is publication number 1569 from the AlfredWegener-Institut.

\section{LITERATURE CITED}

Aagaard K, Fahrbach E, Meincke J, Swift JH (1991) Saline outflow from the Arctic Ocean: its contribution to the deep waters of the Greenland, Norwegian, and Iceland seas. J Geophys Res 96(C11):20433-20441

Aiken GR (1988) A critical evaluation of the use of macroporous resins for the isolation of aquatic humic substances.

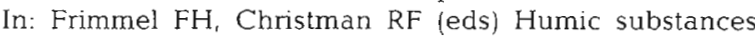
and their role in the environment. John Wiley \& Sons Ltd, p $15-28$

Aiken GR, Mcknight DM, Thorn KA, Thurman EM (1992) Isolation of hydrophilic organic acids from water using non-ionic macroporous resins. Org Geochem 18:567-573

Amon RMW, Benner R (1996) Bacterial utilization of different size classes of dissolved organic matter. Limnol Oceanogr 41:41-51

Bano N, Moran MA, Hodson RE (1997) Bacterial utilization of dissolved humic substances from a freshwater swamp Aquat Microb Ecol 12:233-238

Barber RT (1968) Dissolved organic carbon from deep waters resists microbial oxidation. Nature 220:274-275

Barillier A, Garnier J (1993) Influence of temperature and substrate concentration on bacterial growth yield in Seine River water batch cultures. Appl Environ Microbiol 59:1678-1682

Bauer JE, Williams PM, Druffel ERM (1992) ${ }^{14} \mathrm{C}$ activity of dissolved organic carbon fractions in the north-central Pacific and Sargasso Sea. Nature 357:667-670

Bjørnsen PK, Kuparinen J (1991) Determination of bacterioplankton biomass, net production and growth efficiency in the Southern Ocean. Mar Ecol Prog Ser 71:185-194

Bortz J (1985) Lehrbuch der Statistik: für Sozialwissenschaftler. Springer-Verlag, Berlin

Chin-Leo G, Kirchman DL (1988) Estimating bacterial production in marine waters from the simultaneous incorporation of thymidine and leucine. Appl Environ Microbiol 54:1934-1939

Coble PG (1996) Characterization of marine and terrestrial DOM in seawater using excitation-emission matrix spectroscopy. Mar Chem 51:325-346

Esteves VI, Cordeiro NMA, Duarte AdC (1996) Variation on 
the adsorption efficiency of humic substances from estuarine waters using XAD resins. Mar Chem 51:61-66

Granéli W, Granéli E (1991) Automatic potentiometric determination of dissolved oxygen. Mar Biol 108:341-348

Hoch MP, Kirchman DL (1993) Seasonal and inter-annual variability in bacterial production and biomass in a temperate estuary. Mar Ecol Prog Ser 98:283-295

Ishiwatari R (1992) Macromolecular material (humic substance) in the water column and sediments. Mar Chem 39: 151-166

Jones EP, Anderson LG, Swift JH (1998) Distribution of Atlantic and Pacific waters in the upper Arctic Ocean: implications for circulation. Geophys Res Lett 25:765-768

Kirchman DL, Rich JH (1997) Regulation of bacterial growth rates by dissolved organic carbon and temperature in the equatorial Pacific Ocean. Microb Ecol 33:11-20

Kirchman DL, Suzuki Y, Garside C, Ducklow HW (1991) High turnover rates of dissolved organic carbon during as spring phytoplankton bloom. Nature 352:612-614

Klinkhammer GP, Chin CS, Wilson C, Rudnicki MD, German CR (1997) Distributions of dissolved manganese and fluorescent dissolved organic matter in the Columbia River estuary and plume as determined by in situ measurement. Mar Chem 56:1-14

Kontchou YC, Blondeau R (1990) Effect of heterotrophic bacteria on different humic substances in mixed batch culture. Can J Soil Sci 70:51-59

Krause G (1998) The expedition Arktis-XIII/3 of RV 'Polarstern' in 1997. In: Riemann F (ed) Report to Pol Res No. 262. Alfred-Wegener-Institut für Polar- und Meeresforschung, Bremerhaven, p 13-14

Malcolm RL (1989) Factors to be considered in the isolation and characterization of aquatic humic substances. In: Allard B, Borén H, Grimvall A (eds) Humic substances in the aquatic and terrestrial environment. Springer Verlag, Berlin, p 9-36

Middelboe M, Søndergaard M (1993) Bacterioplankton growth yield: seasonal variations and coupling to substrate lability and b-glucosidase activity. Appl Environ Microbiol 59:3916-3921

Mopper K, Schultz CA (1993) Fluorescence as a possible tool for studying the nature and water column distribution of DOC components. Mar Chem 41:229-238

Moran MA, Hodson RE (1994) Support of bacterioplankton production by dissolved humic substances form three marine environments. Mar Ecol Prog Ser 110:241-247

Moran MA, Zepp RG (1997) Role of photoreactions in the formation of biologically labile compound from dissolved organic matter. Limnol Oceanogr 42:1307-1316

Moriarty DJ, Bell RT (1993) Bacterial growth and starvation in aquatic environments. In: Kjelleberg $S$ (ed) Starvation in bacteria. Plenum Press, New York, p 25-53

Opsahl S, Benner R (1995) Early diagenesis of vascular plant

Editorial responsibility: Fereidoun Rassoulzadegan, Villefranche-sur-Mer, France tissues: lignin and cutin decomposition and biogeochemical implications. Geochim Cosmochim 59:4889-4904

Pfennig N, Widdel F, Trüper HG (1981) The dissimilatory sul-

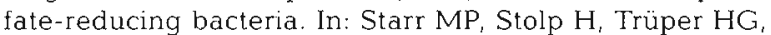
Balows A, Schlegel HG (eds) The prokaryotes. Springer Verlag, New York, p 926-940

Pitter P, Chudoba J (1990) Biodegradability of organic substance in the aquatıc environment, Vol 306. CRC Press, Boca Raton

Pomeroy LR, Sheldon JE, Sheldon WM, Peters F (1995) Limits to growth and respiration of bacterioplankton in the Gulf of Mexico. Mar Ecol Prog Ser 117:259-268

Raven JA, Geider RJ (1988) Temperature and algal growth. New Phytol 110:441-461

Rivkin RB, Anderson MR, Lajzerowicz C (1996) Microbial processes in cold oceans. I. Relationship between temperature and bacterial growth rate. Aquat Microb Ecol $10: 246-254$

Rudels B (1989) The formation of polar surface water, the ice export and the exchanges through the Fram Strait. Prog Oceanogr 22:205-248

Schlegel HG (1985) Allgemeine Mikrobiologie. Georg Thieme Verlag, Stuttgart

Shiah FK, Ducklow HW (1994) Temperature and substrate regulation of bacterial abundance, production and specific growth rate in Chesapeake Bay, USA. Mar Ecol Prog Ser 103:297-308

Simon M, Azam F (1989) Protein content and protein synthesis rates of planktonic marine bacteria. Mar Ecol Prog Ser 51:201-213

Smith SL, Smith WO, Codispoti LA, Wilson DL (1985) Biological observations in the marginal ice zone of the East Greenland Sea. J Mar Res 43:693-717

StatView 4.5 for Macintosh (1994) Abacus Concepts Inc, Berkeley, CA

Thomas DN, Lara RJ, Eiken H, Kattner G, Skoog A (1995) Dissolved organic matter in Arctic multi-year sea ice during winter: major components and relationship to ice characteristics. Pol Biol 15:477-483

Thurman EM (1985) Organic geochemistry of natural waters. M Nijhoff, W Junk (publ), Dordrecht, p 275-361

Tranvik LJ (1988) Availability of dissolved organic carbon for planktonic bacteria in oligotrophic lakes of differing humic content. Microb Ecol 16:311-322

Tranvik LJ (1992) Rapid microbial production and degradation of humic-like substances in lake water. Arch Hydrobiol 37:45-30

Tranvik LJ (1993) Microbial transformation of labile dissolved organic matter into humic-like matter in seawater. FEMS Microbiol Ecol 12:177-183

Wiebe WJ, Sheldon WM, Pomeroy LR (1992) Bacterial growth in the cold: evidence for an enhanced substrate requirement. Appl Environ Microbiol 58:359-364

Submitted: October 1, 1998; Accepted: February 9, 1999

Proofs received from author(s): August 17, 1999 